\title{
ЛЕКСИЧКИ СЛОЈЕВИ ДВАЈУ ПРИМОРСКИХ ТЕСТАМЕНАТА ИЗ XVIII ВЕКА
}

У раду је анализирана лексика двају тестамената насталих на Приморју (Дубровник, Херцег Нови) у првој половини XVIII века. Реч је о тестаментима Хаџи Јова Дукиног Витковића, дубровачког трговца родом из околине Требиња, из 1707. године и Јова Стевановог Делина, трговца са Пода, који је пословао у Венецији, из 1744. године. Документе је објавио Г. Комар 2016. године (Ћириличне опоруке бокешког, требиюског и дубровачког краја 1392-1834).

Лексика ових споменика врло је разнородна и одражава различите културне утицаје под којима је било становништво јужног Јадрана. Уочени су бројни романизми (тестаменат, прокурадури, ереди, динар, иекин), који углавном обухватају правну и економску терминологију и називе монетарних јединица, грецизми и славенизми из сфере православне религиозности (монастир, калуђер, саландар; баштина, одежда, самрт) и турцизми којима се именују предмети из свакодневног живота (долама, мериан, цевердар, тептер).

Кључне речи: тестаменти, јужни Јадран, лексика, етимологија, позајмљенице.

1. Тестаменти (опоруке, завештања) представљају посебан жанр пословне писмености у коме доминира народни језик, будући да је реч о тринаестој од четрнаест установљених рубрика старе српске књижевности [Толстој, 2004: 152-154]. ${ }^{3}$ Порекло тестамента као правног акта везује се за римско право, а током средњег века завештање представља не само последњу вољу, већ и моралну и верску обавезу појединца због легата цркви и добротворним установама [Сиврић, 2009: 195]. ${ }^{4}$

\footnotetext{
${ }^{1}$ nadezda.jovic@filfak.ni.ac.rs

${ }^{2}$ Ово истраживање финансијски је подржало Министарство просвете, науке и технолошког развоја Републике Србије, а рађено је и у оквиру пројекта Српски језик некад и сад: лингвистичка истраживања [360/1-16-10-01] Филозофског факултета у Нишу.

${ }^{3}$ Н. И. Толстој завештања сматра пословним и практичним списима писаним на старом српском пословном књишком језику [2004: 152-154].

${ }^{4}$ Структура и садржај тестамената били су устаљени, а прате их и одговарајуће формуле. У уводном делу (interductio) наводе се име и презиме опоручитеља, датум и место настанка опоруке и напомена о телесном и душевном стању опоручитеља, као и да тестамент пише својом вољом; у средишњем делу (dispositio) пописују се легати црквама и добротворним
} 
1.2. Предмет овог рада биће лексички слојеви језика двају приморских тестамената: дубровачког трговца Хаџи Јова Дукиног Витковића, који је био родом из села Мостаћи из околине Требиња, из 1707. године [Комар, 2016: 39] и новског трговца Јова Стевановог Делина, родом из села Поди, из 1744. године [Комар, 2016: 79].

1.2.1. Тестамент Хаџи Јова Витковића чува се у Државном архиву Дубровника ${ }^{5}$ и има три листа писана брзописном ћирилицом са просечно 35 редова на страни. ${ }^{6}$ Рашчитао га је и два пута објавио Г. Комар [2012: 712-718; 2016: 39-48], обогативши друго издање снимком читавог текста [2016: 43-48]. Садржину опоруке анализирао је М. Сиврић [2009: 202-204], истакавши да је споменик занимљив и због писма и језика. ${ }^{7}$

1.2.2. Тестамент Јова Стевановог Делина сачињен је у Венецији а чува се у Архиву Херцег Новог. ${ }^{8}$ Спада у ред опорука написаних у тренутку изненадне болести током путовања [Комар, 2016: 5]. Писан је брзописном ћирилицом, има четири листа, просечно 36 редова по страни. И овај тестамент издао је Г. Комар објавивши снимке [2016: 84-87, 91-94] и рашчитавши текст [2016: 80-83]. ${ }^{9}$

установама и распоређује се покретна и непокретна имовина родбини и пријатељима; у завршном делу (conclusio) пишу се имена универзалног наследника (errede universale) и сведока, извршитеља опоруке (eppitropi). На крају тестамента честа је формула о неповредивости последње воље [Сиврић, 2009: 197-200].

${ }^{5}$ Према Г. Комару [2012: 42]: Testamenta notariae, сигнатура DAD, T. N, No 73, f. 138-141.

${ }^{6}$ На странама 1r, 2r, 3v има и текста који је писан латиницом приликом предаје тестамента 1707. и његовог отварања 1710. године.

${ }^{7}$ Графијске и језичке одлике овог тестамента анализиране су у раду [Јовић, 2019], где су представљени и овде изнети подаци о дужини споменика, издањима, садржини итд.

Садржина тестамента укратко је ова: одредивши извршитеље тестамента, Хаџи Јово је за опела и помен наменио велики број новчаних легата дубровачким црквама и православним црквама и манастирима од Јерусалима, преко Свете горе, Јадранског приморја и Сарајева, до Фрушке Горе. Оставио је и неколико хуманитарних новчаних легата сиротињи. За главног наследника своје непокретне и покретне имовине одређује супругу Вимију, уколико се не преуда, своју децу и неке рођаке. Осталим многобројним рођацима и пријатељима оставља ситније новчане износе и предмете (нож, ханџар, иглу сребрну, доламе, кожух и сл.). Опорука има и два додатка (aditia), датирана истим датумом као и први део тестамента, у којима Хаџи Јово даје још неке напомене о подели своје имовине.

${ }^{8}$ Прецизне податке - Политичко-управни Млетачки архив, ф. 164, 34 - даје Г. Комар [2016: 83].

${ }^{9}$ У кратким цртама, текст ове опоруке садржи следеће: затечен болешћу у Млецима, далеко од куће, 24. маја 1744. по старом календару, Јово Делин најпре налаже да у случају смрти буде сахрањен у тамошњем православном манастиру Св. Ђорђа, затим наводи приходе и потраживања од радње коју води заједно са Ником Радуловим из Топле, као и улог у послу који га је довео у Млетке. Оставља одређене своте за помене својим родитељима и себи већем броју православних цркава и манастира дуж Јадрана, манастиру Хиландару и јерусалимској 
1.3. Претходна истраживања показала су да су тестаменти писани српским народним језиком источнохерцеговачког типа, што доказују њихове фонетске и морфолошке особине, које ће овде укратко бити представљене. ${ }^{10}$

1.3.1. Од фонетских особина то су: рефлекси јата, јекавско јотовање, супституција сугласника $\phi$, губљење сугласника $x$ [Ивић, 2001: 176-181].

1.3.1.1. Рефлекс јата је (и)јекавски у основи речи и у тврдој заменичкопридевској промени, са фонетским и морфолошким икавизмима (у ДЛ јд. им. женског рода и ДЛ јд. личних заменица, у компаративу придева, у одричним облицима глагола јесам, испред $л$ на крају слога које је прешло у $о$ ).

a) стнєпо $1 \mathrm{r} / 9$, Авнестн $1 \mathrm{v} / 29$, АнєАнт $2 \mathrm{r} / 2$, цвнєтовнћ४ $2 \mathrm{v} / 36$; вБоснеМє н неговнєМє рогћацнма $1 \mathrm{r} / 4$, свнем $2 \mathrm{r} / 24$, Монем старнеМ $3 \mathrm{r} / 28$; Мнаетннон женН снасн $2 \mathrm{r} / 39$; Менн $3 \mathrm{r} / 27$; ннє $2 \mathrm{r} / 31$ итд.;

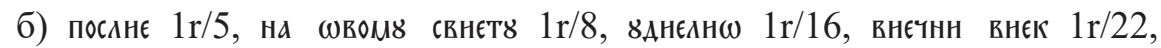
zаповнедНтн $3 \mathrm{r} / 21$, нашєга мнеста $3 \mathrm{r} / 23$; с овнем монем тестаментом $1 \mathrm{r} / 14$; монон д8шн $2 \mathrm{r} / 27$; ннє $1 \mathrm{v} / 5 ;$ доннела $3 \mathrm{r} / 32$ итд.

1.3.1.2. Јекавско јотовање захватило је сугласнике $m$ и $\partial$, што се бележи двогласном графијом ђерв, којом се означавају сугласници $\hbar$ и $\hbar$ :

a) ако Ан нє вн ћєла $3 \mathrm{v} / 23$, сћєпана $2 \mathrm{v} / 14 ;$; $1 \mathrm{r} / 6,2 \mathrm{r} / 14,2 \mathrm{r} / 27$, оћє $1 \mathrm{r} / 6,3 \mathrm{v} / 26$, ћєцє $2 \mathrm{r} / 21$, ћєвонака $2 \mathrm{v} / 30$, када гоћє $3 \mathrm{r} / 18$, ћє вн внћєлн $3 \mathrm{r} / 25$ итд.;

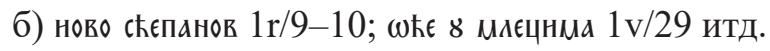

1.3.1.3. Без обзира на порекло позајмљеница (в. 2.3-2.6) сугласник $\phi$ се најчешће супституише са 6 , ређе са $n$, а забележени су и случајеви његовог чувања:

а) стеван $1 \mathrm{r} / 8$, євтану $2 \mathrm{r} / 24,30$; вра домнннкг $1 \mathrm{r} / 15$, авермавам $3 \mathrm{r} / 6$; 8 манастнре врушкв $1 \mathrm{v} / 28 ;$ чевердар $2 \mathrm{v} / 3$, ванде $3 \mathrm{v} / 4$; стнепо $1 \mathrm{r} / 9$, тептер $3 \mathrm{v} / 26$ и др.;

б) афєрмавам (ввн тестаменат $1 \mathrm{v} / 37,3 \mathrm{r} / 36,3 \mathrm{v} / 33$.

1.3.1.4. Губљење сугласника $x$ бележи се у свим положајима, ${ }^{11}$ најчешће у иницијалном. У речи страног порекла щех (в. 2.6), долази до супституције

Цркви Христовог гроба. За главног наследника одређује свога брата, молећи га да се брине о мајци. Супрузи, у случају да се преуда, дозвољава да располаже својом дотом (миразом). Кћери Јани, осим извесних драгоцености, оставља новац на име мираза уз наредбу да се уда у родном месту за хришћанина. Дарује и братанице и ујну. На крају тестамента одређује четири извршитеља. Из додатка писаног 9. јула исте године у Новом, на последњој страни тестамента, сазнајемо да је кћер Јана у међувремену умрла, па оставштину намењену њој расподељује другим лицима. Овај део, страну 4r/19-37, као и формулу: Ја Јово Делин афермавам ови тестаменат, у дну сваке стране (осим 4r) - судећи по рукопису - писао је сам тестатор, док је остали текст писало друго лице.

${ }^{10}$ Језичке особине тестамента Хаџи Јова Витковића, које ће у даљем тексту бити навођене под а), како је поменуто, шире су анализиране у раду [Јовић, 2019], док се језичке особине опоруке Јова Делина овде први пут представљају у оквиру примера под б).

${ }^{11}$ У говору Дубровника сугласник $x$ се чува [Ивић, 2001: 180, 185], али се то није одразило у језику Хаџи Јова Витковића. 


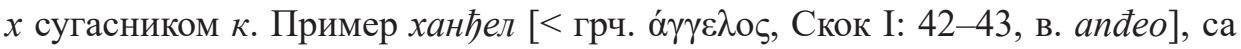
секундарним $x$, одражава несигурност у изговору овог гласа.

а) алнна 2r/16, єрцеговачкомв 2v/23, мандалннн... ромнци $2 \mathrm{v} / 27$; що Бн дооднло АоОАка 3r/26, ће се наоде 3v/26; реко 2r/11, 18, роБова рнсћанскнє 2v/32, итд.; в цекв $3 \mathrm{r} / 23-24$;

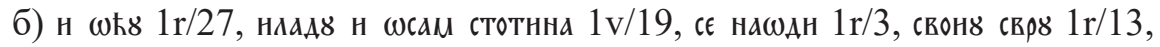
реко саландара 6 2r/22, Фँ моне д४жннка 1v/24-25 итд.; Мога ханћєла раннтела 4r/15.

1.3.2. Од морфолошких катеторија скрећемо пажњу на: промену двосложних хипокористичних имена типа Јово, Иво; готово доследно чување резултата друге палатализације у промени именица женског рода на - $a$ у ДЛ јд.; Г мн. именица са наставком - $а$; ДЛ мн. именица са наставком -ма (с тим што се чешће јављају наставци -ом, -ам) и наставке тврдих заменичких основа у заменичко-придевској промени [Ивић, 2001: 181-183].

1.3.2.1. Имена типа Јово, Иво деклинирају се попут именица мушког рода, што је одлика јужних и југоисточних говора источнохерцеговачког дијалекта [Ивић, 2001: 181]:

а) нова $1 \mathrm{r} / 2$, нва попова $3 \mathrm{v} / 19$; нов8 понавнцин $3 \mathrm{r} / 1$;

б) 8 нстога ннка 2v/34, г(осподнна) снша 2v/35, г(осподнн४) Бож8 2v/17, нстоМ४ ннाк8 $2 v / 33$.

1.3.2.2. Код именица женског рода на - $a$ у ДЛ јд. готово доследно се чувају резултати друге палатализације:

а) дуццн 2v/17, 3r/34, саватнв владнци 2v/22, 23, 24; снасн станннон 2r/392v/1; поред: сивгн 3r/6;

б) г(о)[с]п(о)ћн манццн $1 \mathrm{v} / 14$, в в8тндн $1 \mathrm{v} / 22$, поред: монон госпоћн манкн $2 \mathrm{r} / 20,8$ нстон Б8тнгн $1 \mathrm{v} / 1$.

1.3.2.3. У Г мн. именица јавља се наставак $-a$ :

a) аргата стотнну 1r/11-12, по дннара 10 1r/12, десет ћевонака снрота 2v/30, роБова рнсћанскне десет 2v/32, в т8рака 2v/33, внше речєнне дннара $3 \mathrm{r} / 21$;

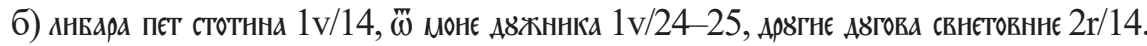

1.3.2.4. ДЛ мн. именица долазе и са наставком -ма (с тим што се чешће јављају наставци -ом, - $а м)$ :

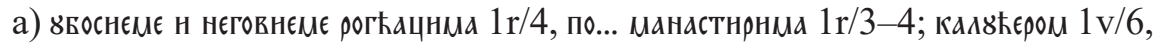
Аатн по Манастнром 2r/20, монем роћаком 2r/23, по царквам $1 \mathrm{r} / 3,3 \mathrm{r} / 27,3 \mathrm{v} / 13$, в р8кам $1 \mathrm{r} / 5$, на галнам 2v/32 итд.;

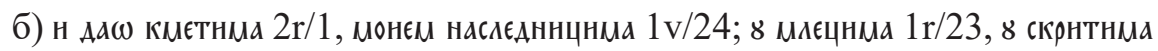
$1 \mathrm{v} / 23$; в неговнеМ Молнтвам 3r/15 итд.

1.3.2.5. У заменичко-придевској промени обични су наставци тврдих заменичких основа:

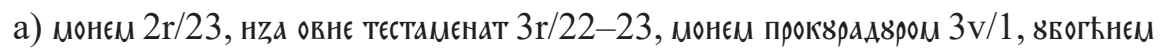
3r/26-27, 3v/6, ФА МОНє ерєАН 3v/9 итД. (В. и 1.3.1.1.a); 
б) с овнем Монем тестаментом 1r/18-19, АрУгНє дУгова свнетовннє 2r/14-15 итД.

1.4. Циљ овог рада је да се покаже како су се различити културни утицаји, којима је било изложено становништво јужног Јадрана, одразили на лексику анализираних тестамената, писаних источнохерцеговачким дијалектом српског народног језика. Осим српскословенске и грчке лексике која је долазила углавном из сфере религије, очекују се романизми и турцизми. Са латинским културним утицајем Словени су се сусрели од насељавања приморског залеђа и Јадранског приморја [Ивић, 1986: 24], док је италијански неколико векова касније постао језик културе и трговине, а затим и администрације. Турски језик продирао је из залеђа, које је од последње четвртине XV века било под турском влашћу, при чему је добар део најбогатијег и најутицајнијег слоја становништва, под притисцима, али и ради очувања своје моћи, брзо примио ислам [Ивић, 1986: 76].

2. Анализа лексике потврдила је присуство свих очекиваних лексичких слојева: доминантне српске народне лексике, српскословенских религијских термина, романизама различитог порекла (латинског, италијанског, француског) - који су најбројније позајмљенице, турцизама, грецизама и малобројних речи из других европских језика (немачког и мађарског).

2.1. У тестаментима доминира српска народна лексика из које се посебно издвајају:

2.1.1. називи родбинских односа: рођак, родитељ, (госпођа) мајка, (покојни господин) отаи, брат /браћа, сестра, ујна, жена / ьубовия, Ђеща, син, кћер, зет, сна(х) а, синоваи, унук;

a) Монем роћаком $2 \mathrm{r} / 23$, роднтела $2 \mathrm{r} / 20$, матєр $1 \mathrm{v} / 3$, отац двка 1v/3, Брату $2 \mathrm{r} / 30$, z Браћом 3a/1, сестрн станн $2 \mathrm{r} / 35$, жена госпоћа внмна $1 \mathrm{r} / 8$, невтановон ћецн 8 мостар $2 \mathrm{v} / 29$, снн алн кћнн $2 \mathrm{r} / 18-19$, моон ћєрн $2 \mathrm{r} / 17$, бетУ мнтру $2 \mathrm{r} / 22$, чєтнрн снаам внтковнћа женам $2 \mathrm{r} / 33$, снновц૪ сладоевв $2 \mathrm{v} / 35$, вн४к8 станннв $2 \mathrm{r} / 37$;

б) манкка 1v/11-12, мога поконнога г(осподнна) б̄ца 2r/18-19, мон Брат 2r/7, враћа ћоровнћн $1 \mathrm{v} / 21$, свакон сестрн $2 \mathrm{v} / 24$, монон 8 ннн $4 \mathrm{r} / 18$, за монв прндрагу аввовцц $3 \mathrm{r} / 26-27$, снротн кћєрн $2 \mathrm{v} / 26$;

2.1.2. правни и економски термини и изрази: имуће 'имовина', очинство 'очевина', наследник, добит, до (x)одак, дуг, дужник; у готову; умруће:

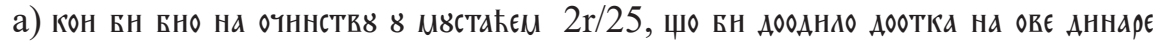
$3 \mathrm{r} / 25-26$;

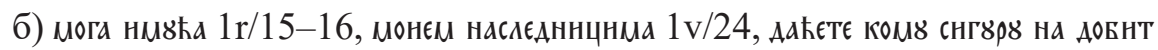

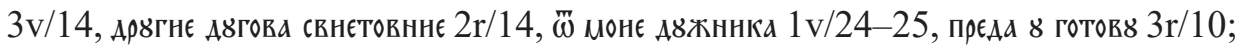
Ad 8 Mour supsћ8 $4 \mathrm{r} / 13$; 
2.1.3. називи за комаде накита: ков [РМС II: 761, ков '2. ковано злато и сребро, као украс на хаљинама и оружју'], прстен, игла:

а) џо є не алнна н кова 2r/16, нгле срєБарнє 2r/30-31;

б) пет прстена $\bar{\omega}$ zлата $3 \mathrm{v} / 3$.

2.2. Српскословенске фонетске особине имају лексеме: баштина, одежда, самрт, саборни, вазнесеније, рождаство, грчаски, васаки, опело, које и језички потврђују конфесионалну припадност опоручитеља:

а) вачнну $1 \mathrm{v} / 1$, одєжду 1v/20, 30, самартн 3v/2, васако лєто $3 \mathrm{v} / 12$, опєло $1 \mathrm{v} / 27$, опєла 3r/27, 3v/12, поред народног: опнєло 1r/18, 20;

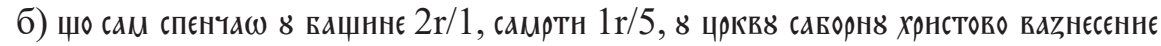
2r/30, рожАаство Пресвете БогоМатере $2 \mathrm{v} / 4-5$, по ГрчаскК $1 \mathrm{r} / 2$.

2.3. Међу позајмљеницама највише је романизама, већином правних и економских термина, назива монетарних јединица, назива за различите врсте накита и др.

2.3.1. Правни термини углавном су старије позајмљенице, у крајњој линији, латинског порекла, али често са фонетским изменама у духу италијанског језика, односно неког од његових дијалеката, у шта се овом приликом неће детаљно улазити. Јављају се термини: тестаменат [PMC VI: 196, тестамен(a)m < лат.], прокурадур / прокуратор 'извршитељ тестамента' [РМС V: 182, прокуратор < лат. '1. онај који управља чим, управитељ; 2. онај који као опуномоћеник заступа кога'], еред [Скок I: 664, hered 'баштиник, наследник, потомак' < лат. heres > тал. erede], авермавати / aфермавати 'потврдити' [РМС I: 113, афирмација < лат. 'потврђивање; потврда, признање'], дота [PMC I: 751, дота < тал. покр. 'мираз'; Скок I: 427-428, dot], ${ }^{12}$ дићарати [PМC I: 680, диктат лат., диктирати]:

а) тастаменат 1r/2, прокврадурн 1r/5, 2r/16, од моне ћнерн ерєдн 3v/11, zа моє

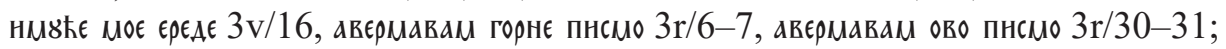

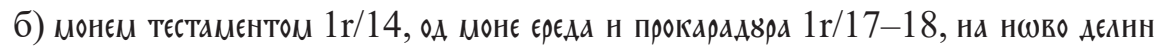

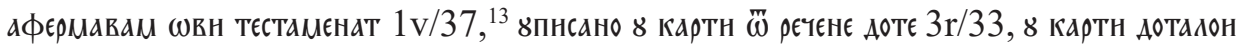
$3 \mathrm{r} / 35$, днћара како нарєћвє $1 \mathrm{r} / 5$.

2.3.2. Економски и трговачки термини већином су италијанског порекла, а неки од њих постали су интернационализми: капитал [РМС II: 657, капитал < лат.], роба [Скок III: 151, rob², roba'1. хесап, стока, трг; 2. материја од које се прави рубље, одећа; рухо, 3. баршун, 4. грабеж', балкански турцизам италијанског порекла, на западу може бити старија позајмљеница

\footnotetext{
${ }^{12}$ Придев дотао, дотала, дотало, изведен од именице дота, није потврђен у прегледаним речницима.

${ }^{13}$ Чување сугласника $\phi$ у овој речи у тестаменту Јове Делина одражава јачи страни језички утицај, што поткрепљује велики број других позајмљеница у језику овог споменика.
} 
из далматороманског], костати [Скок II: 165, koštati < далматоромански остатак], бутига [Скок I: 245, butiga '(трговачки термин) дућан' < тал.], бутига у кумпани 'продавница у сувласништву' [РМС II: 806, компанија фр. '1. друштво..., 2. трговачко или индустријско друштво...'], сума [Скок III: 360, suma 'свота', латинизам или италијанизам, потврђен од XV века], каведао [Скок II: 67, kavedao 'главница' < млет., не пре XVII века], ${ }^{14}$ скрит [Скок III: 270, skrivan; в. skrit, забележено у Боки у значењу 'обвезница' < тал.], конат [Скок II: 137, konat 'рачун' < тал.], израз: учинити конат 'извести рачун', ризик [Скок III: 149, rizik 'одважност, опасност'< интернационални италијански трговачки термин грчког порекла], спенчати 'утрошити' [Скок II: 636, pendžati, у Дубровнику и Цавтату 'трошити, продавати' < далматоромански, италијански], ${ }^{15}$ облегати [Скок II: 537-538, obleg, в. oblegati 'обавезивати', уп. преведеницу облигаиија 'обвезница' < тал.], либро 'пословна књига' [РМС III: 201, либар лат. покр. 'књига' и 202, либро лат. арх. 'либар']:

б) џо є чнега капнтала $1 \mathrm{v} / 30$, сва рова коста ме $1 \mathrm{v} / 6$, нмам єАНУ в8тнгУ коа

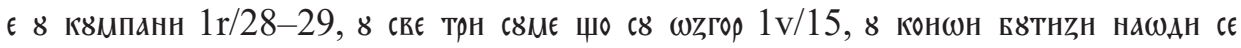

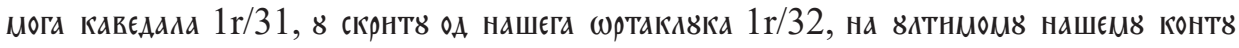
1v/1, како смо 8чнннндн конат 1v/28-29, в двковнћа на рнднкк8 1v/13, що сам спенчаш

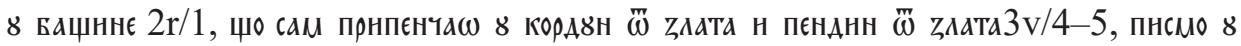

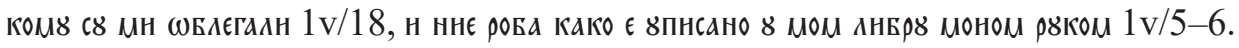

2.3.3. Посебно издвајамо називе монетарних јединица, које су биле у употреби у градовима на Јадрану и у јадранском залеђу. Они представљају позајмљенице различите старине, а некада и путева позајмљивања: динар [Скок I: 405-406, dinar < лат., стара позајмљеница присутна у старословенским рукописима], дукат [PMC I: 804, дукат тал. 'млетачки новац из XIII столећа; златни новац различне вредности уопште'], грош [Скок I: 624-625, groš 'бакрен новац' < од тал. преко немачког], цекин [Скок I: 255, ceka, в. cekin 'млетачки дукат' < тал.], либра [Скок II: 293, libra '1. новац, енглеска фунта, 2. мера за тежину' < тал.], мунида [Скок II: 454, moneta; в. munita, у Дубровнику, munida, у Перасту 'ситни звечећи новац', у овим облицима може бити далматоромански језички остатак], газета [Скок I: 557, gazeta 'стари мали бакарни млетачки новац' < тал. < грч.], солда [Скок III: 304, solda 'новац' < тал.]:

a) дннара $1 \mathrm{r} / 12,3 \mathrm{r} / 5$, двката $1 \mathrm{r} / 12$, гроша 25 1r/14, цєкнна 4 1v/27;

б) по двката двадеєет н пєт $2 \mathrm{v} / 18-19$, цекнна сто $1 \mathrm{v} / 10-11$, цекнна пєт $2 \mathrm{v} / 12$,

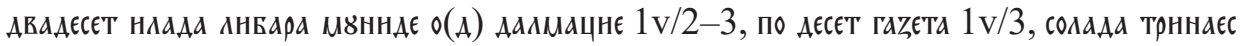
$1 \mathrm{v} / 7$.

\footnotetext{
${ }^{14}$ Номинатив преузет од П. Скока будући да пример долази у ген. мога каведала.

${ }^{15}$ У прегледаним речницима није потврђен префиксални облик глагола пенчати-припенчати, чије је значење из контекста у тестаменту Јове Делина реконструисано као 'уложити'.
} 
2.3.4. Италијанског порекла су називи за различите врсте накита који се појављују као предмет оставине: кордун [Скок II: 153, korda 'ланац', kordun, у Рисну, потврде из XVI века, '1. широка трака, врпца на шеширу, 2. међа, граница, 3. ланац' < тал.], пендин [Скок II: 636, pendjun 'наушнице у жена', в. pendin, у Дубровнику 'драги камен који се носи о врату' < тал.], манина [Скок II: 370, manina 'наруквица' < тал.], медаља [Скок II: 397, medalja 'медаљон' < фр. или тал.]:

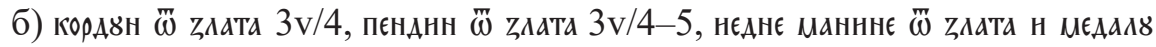
का zлата $3 \mathrm{v} / 10$.

2.3.5. Има и разноврсне друге лексике романског порекла: галија [Скок I: 547, galija 'велики брод на весла' < тал.], вол [РМС I: 416, волумен лат. '1. обујам, обим, садржај; запремина, 2. свезак, књига, том;'], сигуро [Скок III: 233, sikur 'поуздан' < тал., промена $\mathrm{k}>\mathrm{g}$ из млетачког дијалекта], карта [Скок I: 658, harta '1. папир, 2. лист у књизи, 3. карта код игре' < тал. carta $<$ лат. charta < грч.], непуча [Скок II: 511, периt 'рођак', дем. непучица 'сестрина, братова кћи, унука, ... нећакиња' < далмато-романски лексички остатак из терминологије сродства], комунитад [Скок II: 136, komun 'општина', у Паштровићима комунитад < тал.], кужина [Скок II: 224, kuhati < лат. преко старовисконемачког; kužina, на Јадрану, позајмљеница из млетачког], нота [Скок II: 545, nota '2. писмено саопштење' < тал.], доктур [Скок I: 423, doktur, Дубровник XV век < лат.], кастел [Скок II: 57-58, kaštel 'градац, град, кула' < тал. < лат.]:

а) на галнам 2v/32, парвн вол 3r/14, да є Боле н снквурне 3v/4, снгуро место 3v/24;

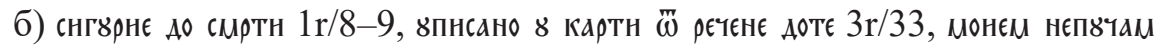

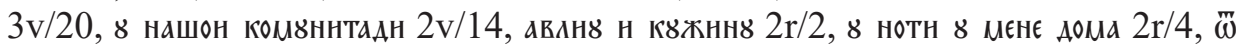
АОКтУРА КАШТЕАН Н(с) спнєТА $2 \mathrm{r} / 10$.

2.4. Грецизми у анализираним тестаментима претежно су термини из сфере религије: манастир [РМС III: 292, манастир], калуђер [PМС II: 637, калуђер], поп [PMC IV: 702-703, nоn ${ }^{1}$ ], летурђија [PMC III: 197, летургија, летурђија], саландар [РМС V: 615, саландар 'награда калуђерима за молитве мртвима између Ускрса и Спасовдана'], трпеза [PMC VI: 309, трпеза грч. '1. сто, 2. јело, обед, 3. даћа'], али и други називи: apгат [Скок I: 59, argatin 'надничар', балкански грецизам], иљада [Скок I: 666-667, hiljada]:

а) по... манастнрниа 1r/3-4, калвгћєр $1 \mathrm{r} / 9$, попь 2r/21, понв летвргћнє $1 \mathrm{v} / 2-3$, саландар велнкн 1r/18, 20, тарпеСе по Манастнрнда н опнела 3v/20-21; аргата $1 \mathrm{r} / 11$;

б) нлада н (есам стотнна 1v/19, в цркве н монастнре 2r/16, шес саландара 2r/19.

2.5. Турцизми су у XVIII веку били лексички слој чврсто утемељен у речнику становништва које је готово три века било у контакту са носиоцима турског језика. У тестаментима Јова Вуковића и Јова Делина речима турског порекла именују се: 
2.5.1. различити предмети и појмови из свакодневног живота, укључујући и религију: авлија [Шкаљић, 1989: 106, avlija < грч.], алат терзински [Шкаљић, 1989: 85, alat; 613, terzija], долама [Шкаљић, 1989: 222, dolama 'врста старинске мушке и женске ношње, слична капуту'], мериан [Шкаљић, 1989: 459, merdžan 'корал'], копча [Скок II: 146-147, kорс̌a 'дугме, пуце' < балкански турцизам], ракија [Шкаљић, 1989: 530, rakija]; ащи [Шкаљић, 1989: 296, hadžija, hadži 'онај који је извршио хаџ...']:

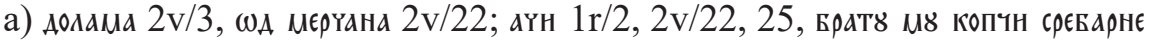
$2 \mathrm{r} / 30$;

б) в ракнн $1 \mathrm{v} / 28$, авлнв н къжннв $2 \mathrm{r} / 2$, мон алат терДннскК $2 \mathrm{v} / 34$;

2.5.2. називи оружја: аниар [Шкаљић, 1989: 310, handžar 'дуги шиљасти нож'], цевердар [Шкаљић, 1989: 235, džeferdar 'врста старинске пушке која је украшена седефом и драгим камењем'];

a) анчар МОН окованн $2 r / 37$, чевєрАар $2 v / 3$;

2.5.3. појмови из сфере економије и трговине: вајда [Шкаљић, 1989: 275, fajda, vajda 'корист, добит'], вересија [Шкаљић, 1989: 640, veresija 'продаја на кредит'], ортаклук [Шкаљић, 1989: 503, ortakluk 'заједница, пословно удруживање'], тептер [Шкаљић, 1989: 606, tefter, tevter, defter 'бележница, регистар, протокол, трговачка књига дуговања и потраживања']:

a) OA Oвє ванде $3 \mathrm{~V} / 4$, тептер $3 \mathrm{~V} / 26$;

б) ४ скрнту од нашега Фртакл४ка 1r/32, наплатн вересн8 3r/9-10.

2.6. Ретке су позајмљенице из других језика попут германизма цек [PMC VI: 789, иех нем. '1. ист. сталешко удружење занатлија, обртника једне струке'...] и хунгаризама варош [PМC I: 333, варош маџ.], маиарија [Скок II: 349-350, Madžar, в. madžarija 'мађарски / аустријски дукат']:

a) 8 цєкв $3 \mathrm{r} / 23-24,3 \mathrm{v} / 3-4$; мачарна $1 \mathrm{v} / 4,7,9$;

б) на варошн 8 новомв $1 \mathrm{v} / 19$.

3. Већина овде поменутих лексема преузетих их страних језика представља такозвану цивилизациону лексику, у коју спадају речи (позајмљене, нове или старе са новим или промењеним значењем) „које су улазиле у језик услед политичких, друштвених, економских промена или због нових предмета, нових проналазака итд.“ [Невекловски 2008: 248]. Сигурно је и да број позајмљеница у језику прегледаних тестамената не би био толики да њихови носиоци нису житељи трговачких центара (Дубровник, Херцег Нови), у којима је у живој употреби био италијански као језик трговине, културе и администрације, што ствара готово билингвалну средину у којој je, по правилу, туђица много више него у срединама где тога нема [ЕРСJ, 1998: XVI]. Значајно је да је, упркос томе, како је показано у 2.1.1, терминологија родбинских односа остала словенска. 
3.1. Иако два анализирана тестамента спаја занимање опоручитеља (трговина која подразумева језичке контакте), географски и језички простор (урбани делови јужног Јадрана и источнохерцеговачки дијалекат) и време настанка (XVII век уз разлику од скоро четири деценије) - међу њима постоје и видне разлике у погледу употребе позајмљеница.

Тестамент Хаџи Јова Витковића, трговца пореклом из приморског залеђа, има нешто више турцизама и знатно мање романизама, при чему не бележи романизме из сфере економске терминологије (2.3.2) и називе за врсте накита (2.3.4). Јово Делин, пореклом из околине Херцег Новог, диктирао је своју опоруку у Венецији четрдесетак година касније, што може имати утицаја на појачано присуство економске терминологије романског порекла у њеном језику.

3.2. У фонетском лику неких позајмљеница из оба тестамента могу се уочити гласовне промене у духу народног језика, у виду нестабилности гласова $\phi$ и $x$ (авермавати, вајда, тептер; еред, иљада, аниар, аии, иеек), које јасно упућују на њихову одомаћеност у то време. Чување сугласника $\phi$ у речи афермавати у опоруци Јова Делина у складу је са јачим страним језичким утицајем који се у језику ове опоруке очитује и већим бројем позајмљеница.

Локалнији карактер имају романизми у тестаменту Јова Делина: $м y$ нида, пендин, непуча, доктур, кордун, комунитад, који су, према подацима пронађеним код П. Скока, забележени у облицима обичним у Дубровнику, Рисну и Перасту.

3.3. Међу анализираним лексемама уочено је неколико синонимских парова: имуће - баштина, умруће - самрт, жена - љубовца, од којих издвајамо: рођака - непуча, ортаклук - кумпана, тептер - либро, који показују прожимање, али и границу културних утицаја на релацији залеђе-приморје, што би требало проверити на ширем и разноврснијем корпусу.

3.4. Романизми бутига, ичекин, галија, карта, комунитад, конат, кордун и др., забележени у тестаменту новљанског трговца Јова Делина, потврђени су у говорима Боке Которске [Мусић, 1972; Липовац-Радуловић, 1981].

4. Могло би се закључити да су се тестаменти из прве половине XVIII века, двојице приморских трговаца - Дубровчанина Хаџи Јова Дукиног Витковића, родом из околине Требиња и Јова Стевановог Делина, родом из места Поди - показали као веома захвална грађа за лексичка истраживања. Писани народним језиком, источнохерцеговачким дијалектом, они обилују разговорном лексиком у којој се одражавају различити културни утицаји на 
овом подручју. Удео лексике страног порекла разликује се у прегледаним споменицима. У опоруци писаној касније, половином XVIII века, више је позајмљеница што, једним делом, свакако, зависи и од језичких одлика појединца, али може одражавати и јачи страни културни утицај у овом периоду, што би требало проверити на обимнијој грађи.

Лексика ових опорука сугерише да у првој половини XVIII века на јужном Јадрану доминира романски културни утицај у сфери правне и економске терминологије, као и у називима за врсте новчаних јединица. Значајније су присутни још и турцизми различитог значења. Грецизми су углавном везани за православну религију, док је број осталих позајмљеница занемарљив. Терминологија родбинских односа остала је словенска у оба тестамента. У речима страног порекла огледају се неке од особина народног језика, нпр.: супституција сугласника $\phi$ (авермавати, вајда, тептер), губљење гласа $x$ (еред, иљада, аниар, аџи) или његова супституција (цек) - које упућују на то да су се ове речи одомаћиле и ушле у ширу употребу.

\section{Литература}

ЕРСЈ, 1998: Оаледна свеска, Библиотека Јужнословенског филолога н. с. 15. Београд: Етимолошки одсек Института за српски језик САНУ.

Ивић, 1986: П. Ивић, Српски народ и његов језик. Београд: СКЗ.

Ивић, 2001: П. Ивић, Дијалектологија српскохрватског језика: увод и штокавско наречје, (Приредио: Драгољуб Петровић), Целокупна дела П. Ивића; т. 2. Сремски Карловци - Нови Сад : Издавачка књижарница Зорана Стојановића.

Јовић, 2019: Н. Јовић, О језику тестамента Хаџи Јова Дукиног Витковића из 1707. године, у: Друга научна конферениија Српско писано насљеђе и историја средњовјековне Босне и Хума, Требиње, 21-22. јуна 2019. године. Филолошки факултет Универзитета у Бањој Луци - Филозофски факултет Унивезитета у Источном Сарајеву · Филозофски факултет Универзитета у Бањој Луци · Друштво наставника српског језика и књижевности Републике Српске · Удружење историчара Републике Српске „Милорад Екмечић“ (у штампи).

Комар, 2012: Г. Ж. Комар, Ћирилична документа Дубровачког архива, Прилози историји свакодневног живота на тромеђи Дубровника, Требиња и Новог 1395-1795 (треће допуњено и измјењено издање). Херцег Нови: Друштво за архиве и повјесницу херцегновску.

Комар, 2016: Г. Ж. Комар, Ћириличне опоруке бокешког, требињског и дубровачког краја 1392-1834, (Приредио: Горан Комар). Херцег Нови: Друштво за архиве и повјесницу херцегновску.

Липовац-Радуловић, 1981: V. Lipovac-Radulović, Romanizmi и Crnoj Gori jugoistočni dio Boke Kotorske. Cetinje - Titograd : Obod - Pobjeda. 
Мусић, 1972: S. Musić, Romanizmi u severozapadnoj Boki Kotorskoj. Beograd : Filološki fakultet.

Невекловски, 2008: Г. Невекловски, Цивилизациона лексика у српском и хрватском језику у XIX веку. Јужнословенски филолог LXIV, 247-260.

PMC: Речник српскохрватскога књижевног језика, I-III. Нови Сад: Матица српска - Загреб: Матица хрватска, 1967-1969; IV-VI. Нови Сад: Матица српска, 1971-1976.

Сиврић, 2009: M. Sivrić, O oporuci - struktura i sadržaj s osvrtom na oporuke trebinjskih oporučitelja do 1808. godine. Tribunija br. 12, 195-207.

Скок: P. Skok, Etimologijski rječnik hrvatskog ili srpskoga jezika I-IV. Zagreb: JAZU, 1971-1974.

Толстој, 2004: Н. И. Толстој, Студије и чланции из историје српског књижевног језика. Београд - Нови Сад : Завод за уџбенике и наставна средства · Вукова задужбина · Матица српска.

Шкаљић, 1989: A. Škaljić, Turcizmi u srpskohrvatskom jeziku. Šesto izdanje. Sarajevo: Svjetlost.

Nadežda D. Jović

\section{LEXICAL LAYERS IN TWO TESTAMENTS FROM THE EIGHTEENTH CENTURY ORIGINAITING FROM THE SOUTHERN ADRIATIC}

The paper analyzes the lexis of two testaments incurred on the south Adriatic coast (Dubrovnik, Herceg Novi) in the first half of the eighteenth century. It is a testament of Haji Jovo Dukin Vitkovic, Dubrovnik merchant born in the area of Trebinje, from 1707, and of Jovo Stevanov Delin, a merchant from Podi, which operated in Venice, from 1744. Documents were published by G. Komar 2016 (Ćirilične oporuke bokeškog, trebinjskog i dubrovačkog kraja 1392-1834).

Lexicon of these monuments is very diverse and reflects the different cultural impacts on the population of the southern Adriatic. There were observed numerous Romancisms (testament, prokuradur, eredi, dinar, cekin), which were mostly the legal and economic terms and names of monetary units, Greek and slavic lexical elements from the sphere of orthodox religiosity (monastir, kaluđer, salandar; baština, odežda, smart) and the turkish borrowings which assigning objects from everyday life (dolama, merdžan, dževerdar, tepter).

Keywords: testaments, southern Adriatic, vocabulary, etymology, borrowings. 